\title{
Smart-Home Technologies to Assist Older People to Live Well at Home
}

Meg E. Morris ${ }^{1 *}$, Brooke Adair ${ }^{1,3}$, Kimberly Miller², Elizabeth Ozanne ${ }^{3}$, Ralph Hampson ${ }^{3}$, Alan J. Pearce ${ }^{1,4}$, Nick Santamaria ${ }^{3,5}$, Luan Viegas $^{1}$, Maureen Long' ${ }^{1}$ and Catherine M. Said ${ }^{1}$

${ }^{1}$ Departments of Physiotherapy and Social Work, School of Allied Health, La Trobe University, Melbourne, Australia

${ }^{2}$ Department of Physical Therapy, University of British Columbia, Vancouver, Canada, and Department of Physiotherapy, The University of Melbourne, Melbourne, Australia

${ }^{3}$ School of Health Sciences, The University of Melbourne, Melbourne, Australia

${ }^{4}$ Cognitive and Exercise Neuroscience Unit, School of Psychology, Deakin University, Melbourne, Australia

${ }^{5}$ Royal Melbourne Hospital, Melbourne, Australia

\begin{abstract}
Background: With the rapid population ageing that is occurring world-wide, there is increasing interest in "smart home" technologies that can assist older adults to continue living at home with safety and independence. This systematic review and critical evaluation of the world wide literature assesses the effectiveness and feasibility of smart-home technologies for promoting independence, health, well-being and quality of life, in older adults.
\end{abstract}

Methods: A total of 1877 "smart home" publications were identified by the initial search of peer reviewed journals. Of these, 21 met our inclusion criteria for the review and were subject to data extraction and quality assessment.

Results: Smart-home technologies included different types of active and passive sensors, monitoring devices, robotics and environmental control systems. One study assessed effectiveness of a smart home technology. Sixteen reported on the feasibility of smart-home technology and four were observational studies.

Conclusion: Older adults were reported to readily accept smart-home technologies, especially if they benefited physical activity, independence and function and if privacy concerns were addressed. Given the modest number of objective analyses, there is a need for further scientific analysis of a range of smart home technologies to promote community living.

Keywords: Elderly; Older people; Smart-homes; Smart-technologies; Home

\section{Introduction}

We conducted a systematic review and critical evaluation of the effectiveness and feasibility of smart-home technologies to assist older adults to live well, safely and independently at home. Improved health and social care over recent years has increased life expectancy worldwide. As a result nearly $7 \%$ of the world's population is now over 65 years of age [1]. The proportion of older people is predicted to rise approximately $20 \%$ by 2050 worldwide [1]. The increasing number and proportion of older adults requires a greater focus on policies and resources to meet their needs. Smart home technologies encourage and allow elderly people to live longer in their own homes [2].

Increased longevity is often associated with increased susceptibility to diseases and injury [3]. Chronic diseases such as cancer, diabetes, arthritis, heart disease and chronic obstructive pulmonary disease are common in older adults. Falls and injuries are also more common in elderly people [4]. It has been predicted that by 2035 , the proportion of people with dementia will double [5] and by 2050, the number of fulltime carriers will have tripled [6]. With the current trends in population demographics, it is becoming increasingly difficult for governments worldwide to fully support the health and social care systems [7]. The use of smart technologies, including smart-homes could arguably relieve the pressure on aged care health and social support services [8].

Smart homes are purpose designed living spaces that provide interactive technologies and unobtrusive support systems to enable people to enjoy a higher level of independence, activity, participation or well-being than otherwise afforded $[9,10]$. The smart homes movement links together the fields of housing, technology, engineering, sociology, and healthcare in relation to robotics, sensors, tele-health, ergonomics, communications, social care and safety $[11,12]$. Home based smart technologies can sometimes enable people to live in their own home rather than being hospitalized or institutionalized [10]. Smart-home technologies can also promote independent living and safety. This has the potential to optimize quality of life and reduce the stress on agedcare facilities and other health resources [13].

The challenge with smart-home technologies is to create a home environment that is safe and secure to reduce falls, disability, stress, fear or social isolation [14]. Contemporary smart home technology systems are versatile in function and user friendly. Smart home technologies usually aim to perform functions without disturbing the user and without causing any pain, inconvenience or movement restrictions. Martin and colleagues performed a preliminary analysis of the acceptance of smart-home technologies [15]. The results from this review were limited as no studies met inclusion criteria [15]. Given however, the rapid progression of new smart home technologies, a new systematic review of the literature is required. This paper addresses that need by analysing the range of studies undertaken to assess the impact of these technologies on the quality of life experienced by an ageing population accessing these supports. The broader context incorporates consideration of the social and emotional well-being needs of this population. The current review aimed to answer the following research question: "What is the effectiveness of smart-home technologies for

*Corresponding author: Meg E. Morris, Departments of Physiotherapy and Social Work, School of Allied Health, La Trobe University, Melbourne, Australia Tel: +61 39479 6080; Fax: +61 39479 5768; E-mail: m.morris@latrobe.edu.au

Received January 20, 2013; Accepted March 02, 2013; Published March 07, 2013

Citation: Morris ME, Adair B, Miller K, Ozanne E, Hampson R, et al. (2013) SmartHome Technologies to Assist Older People to Live Well at Home. Aging Sci 1: 101. doi: 10.4172/2329-8847.1000101

Copyright: (c) 2013 Morris ME, et al. This is an open-access article distributed under the terms of the Creative Commons Attribution License, which permits unrestricted use, distribution, and reproduction in any medium, provided the original author and source are credited. 
promoting health, well-being and quality of life enabling older people to remain living at home and in the community"? Smarthome technologies are generally installed in a person's community based residence. Therefore, we also investigated the feasibility, acceptance and perceptions of these forms of technology in a home environment

\section{Methods}

\section{Search strategy}

The database search was conducted in November 2012 The following databases were searched: MEDLINE, Web of Science, CINAHL, Scopus, Rehabilitation Reference Center, Nursing Reference Center, Cochrane Central Register of Controlled Trials, Inspec, Compendex, SocINDEX, PsychINFO and Sociological Abstracts. These databases were chosen as they cover a broad range of disciplines ranging from health to social sciences and the life sciences.

A variety of search terms synonymous with keywords such as 'elderly' and 'smart homes' were combined using Boolean logic. An example of the search strategy utilized for the MEDLINE search is given in table 1 .

\section{Study selection}

A trained reviewer scanned the titles of the entire yield once the search was completed. Duplicates and articles that did not meet inclusion criteria were removed. The titles and abstracts of the remaining articles were then reviewed independently by two trained reviewers against pre-determined inclusion criteria. Studies that were judged to be irrelevant were excluded. If the reviewers were unsure, studies remained for review of the full text. Data extraction and quality assessment were performed for the full texts that met inclusion criteria. Any discrepancies in study inclusion or data extraction were reconciled by mutual agreement.

\section{Selection criteria}

The selection criteria for this review are shown in table 2. Articles were included if they were published in English, in a peer reviewed text, and were available as full works. Because of the rapid progression in technology [16] and the relative lack of information in earlier years [15], articles published before January 2000 was excluded. This study was interested in original information regarding the effectiveness or feasibility of smart-home technologies. Accordingly, the search was limited to intervention or feasibility studies. Narrative reviews and other systematic reviews were excluded as they did not meet inclusion criteria. For the purpose of this review, studies were considered to assess the effectiveness of the smart home technology when they were randomized control trials or if they incorporated an intervention period with an assessment before and afterwards.

'Home' was defined as a person's place of living, according to the Merriam Webster Dictionary [17]. A 'home' environment may include a private residence, supported accommodation, independent living, retirement villages and service-integrated housing. Due to issues with patents and intellectual information and residents not wanting to make permanent modifications to their homes for the purpose of a study, some researchers may choose to use purpose built smart-homes which are often associated with laboratories. Such settings were also included as people were able to live in the 'house' and the setting was therefore considered to be a 'home' environment. Hospital environments and nursing home facilities sometimes provide residents with considerable physical and psychological assistance, often by trained professionals. Consequently studies in nursing homes and hospitals were excluded.

Throughout this study a broad definition of "older people" was adopted as defined by MeSH definitions. These were 'middle-aged' (aged 45-64 years), 'aged' (65-79 years) and 'aged $80+$ years'. Thus, studies which included any participants 45 years or older were considered for our systematic review. Tele-rehabilitation and tele-health have been topics of interest in recent years, particularly with the ongoing management of various chronic conditions [18].

This form of technology generally involves interaction with a remote health practitioner and is therefore still reliant on the medical system for support. Consequently, studies of tele-rehabilitation or tele-medicine based management techniques were excluded from this particular review and we reviewed that material separately. There are multiple forms of technology that may help to assist older adults in their home environments. It was beyond the scope of this paper to review the robotics, gaming or social inclusion literature. We have reviewed these separately. Instead, the focus of this paper was specifically on types of technology that can be used in a home environment which either interacts with or provides direct information to the user without the need for another individual.

\section{Data extraction and quality assessment}

Data extraction was performed using a customized data extraction form. Details such as the aims of the study, the settings where the study

\begin{tabular}{|c|c|}
\hline Keyword & Synonyms \\
\hline Elderly & Middle aged or Aged or Aged, 80 and over or Age* or Aging or Elder* or "Older adult" or "Older person" or "Older people*" \\
\hline Smart-home & $\begin{array}{l}\text { "Smart home*" or "ambient assisted living" or "ubiquitous home*" or "ubiquitous technology" or "electronic assistive technology" or } \\
\text { "social alarm" or "telecare social alert platform*" or "environmental control system" or "automated home environment" or telehomecare } \\
\text { or "Home Automation" }\end{array}$ \\
\hline
\end{tabular}

Note: Synonyms for the two keywords were combined to create search strategy.

Table 1: Example of search strategy for MEDLINE.

\begin{tabular}{|c|c|}
\hline Inclusion Criteria & Exclusion Criteria \\
\hline 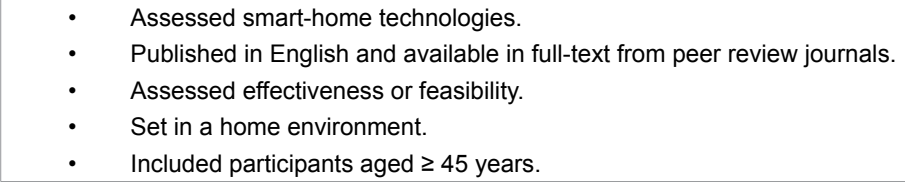 & $\begin{array}{l}\text { - } \quad \text { Published before January } 2000 . \\
\text { - } \quad \text { Set in other environments such as nursing homes or rehabilitations settings. } \\
\text { - } \quad \text { Studies focussed on tele-health, tele-medicine or tele-rehabilitation. } \\
\text { - } \quad \text { Narrative reviews and other systematic reviews. }\end{array}$ \\
\hline
\end{tabular}

Table 2: Inclusion and exclusion criteria. 
was performed, the methods of recruitment and sampling, feasibility, outcome measures and results were recorded. When considering the appropriateness of different technologies it may be beneficial to consider the amount of assistance and training required for use. The role of smarthome technologies is often to assist residents by performing a task they are no longer able to do. In this way, many smart-home technologies should be able to work independent of the people who reside in the house. As a result the level of assistance has not been reported in this study. Due to the heterogeneity of results and the lack of randomized controlled trials, a meta-analysis was not feasible in this study. Instead a summative synthesis of results was performed [19].

As this study aimed to highlight intervention studies, the Downs and Black [20] quality checklist was chosen. This tool has been specifically designed to assess the quality of randomized or nonrandomized intervention studies [20]. The tool has 27 items which are generally answered as 'yes', 'no' or 'unable to determine'. Scores are assigned to each answer and are summed to create a total quality score. The last item of this tool was found to be ambiguous. Similar to previous studies which also used this tool, the last item was removed resulting in a 26 -item checklist $[16,21,22]$. The highest possible score in the revised version of the tool was 27 .

\section{Results}

The initial search of the selected databases yielded a total of 1877 publications. The number of articles assessed at each stage of this review is shown in figure 1. Many articles were excluded because they focused on describing different forms of smart-home technology and the electronic architecture behind them, rather than assessing their effectiveness or feasibility [23]. Several studies were initially considered appropriate for inclusion but following more detailed review were excluded for various reasons. One study tested a new program but was excluded because the reviewers felt the technology included more tele-health than smarthome components [24]. A study by Croser et al. [25] was originally included as it investigated the effectiveness of different technologies on activities of daily living in people with various disabilities. On closer review it was noted that although the study included one person older than 45 ( 58 years old) it also included data from three children (aged 6-13 years) [25]. Theoretically, the feasibility and effectiveness of smart-

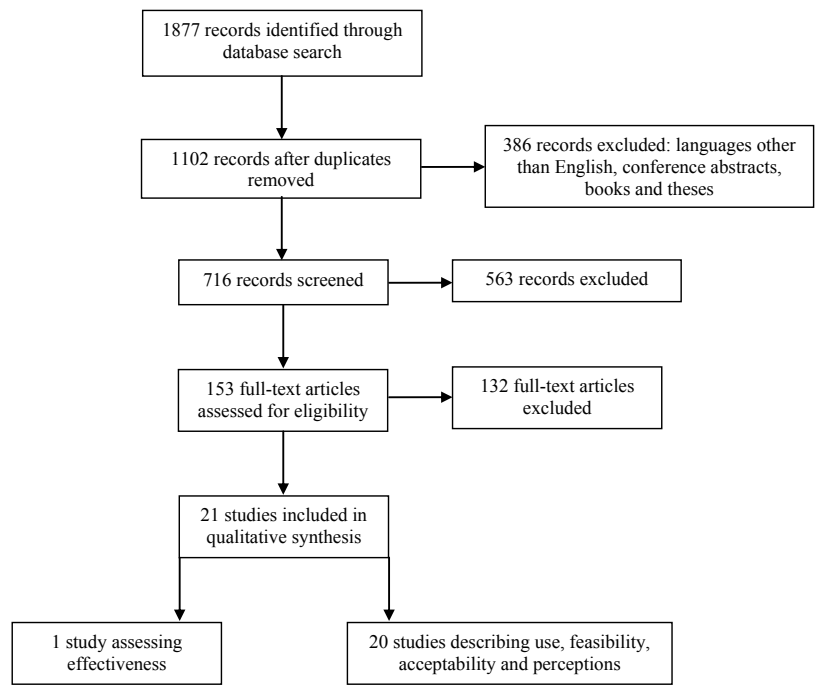

Figure 1: Yield of studies identified during each step of this review. home technologies may be different in children compared with the elderly. Consequently this study was excluded.

\section{Study characteristics}

In total, 21 studies underwent data extraction. A description of each of the articles included in this review is provided in table 3 . One assessed the effectiveness of smart-home technologies and was also assessed for its methodological quality [26]. Sixteen studies reported on feasibility or perception of smart-technologies [27-43]. Three studies, based on an observational design, described how smart technologies worked with various participants and often combined qualitative comments regarding feasibility [44-46]. One study was described as a cohort study and described the ability to perform activities of daily living using a form of smart-technology [45]. This study did not use a control group or perform comparison measures and therefore was not considered to report on the effectiveness of the smart-home technology [45].

According to the National Health and Medical Research Council of Australia guidelines, the level of evidence of most of the studies was grade IV. Most studies assessed the various sensors available for use in smart-homes. Five studies were set in purpose built smart-homes or residences already incorporating smart-technologies $[30,36,41,43,46]$. Three studies used focus groups to discuss the potential for smarttechnologies and were therefore not based in any particular setting $[27,35,39]$. Consequently the settings for these studies were recorded as not applicable.

\section{Participant characteristics}

The characteristics of the participants in the included studies are shown in table 4 . The sample size ranged 1-78. While some studies included younger people the age of the participants in most studies was over 65 years. The health characteristics of study participants were heterogeneous. Some studies included healthy older adults, while others included participants with neurological deficits. Four studies assessed the perceptions of carriers, facility staff or family members of elderly people [35-39,43].

\section{Feasibility of smart-home technologies}

Details regarding the feasibility of smart-technologies as reported in different studies are provided in table 5 . Four studies identified possible safety issues. These included an increased risk of tripping on misaligned carpet [30], systems failing during emergencies [37], the possibility that incorrect medication dosages could be taken but not recorded [41] and concerns regarding the functioning of home adaptations during power outages [42]. Nine studies identified privacy issues arising from utilization of smart-home technologies [28,29,31-35,42,43]. Two reported that privacy was a barrier to people choosing to install and use smart-home technologies $[28,29]$. Most of the participants reported that cameras and monitoring systems invaded their privacy and left them with a sense that they were being watched.

Many of the studies did not document the cost of the smarttechnologies nor the level of training required to use it. Two reported 'low cost' technology [40,44], one quoted less than $\$ 400$ [26] and one study reported that the highest price to retro-fit a home was $€ 13500$ [42]. Four studies reported satisfactory use with only brief training provided when the technology was installed or before the assessments were performed $[26,30,45,46]$.

Overall the studies that assessed perceptions and acceptability found that smart-home technologies were generally readily accepted 
Citation: Morris ME, Adair B, Miller K, Ozanne E, Hampson R, et al. (2013) Smart-Home Technologies to Assist Older People to Live Well at Home. Aging Sci 1: 101. doi: 10.4172/2329-8847.1000101

Page 4 of 9

\begin{tabular}{|c|c|c|c|c|c|c|c|}
\hline Study & $\begin{array}{l}\text { Level of } \\
\text { evidence }\end{array}$ & Study design & Study aims & Description of ST & Setting of ST & Region & $\begin{array}{l}\text { Sampling } \\
\text { strategy }\end{array}$ \\
\hline Beckwith [43] & IV & Qualitative & Acceptance and perceptions & $\begin{array}{c}\text { Door switches, movement sensors, } \\
\text { bed load cells, individual tracking } \\
\text { badges. }\end{array}$ & $\begin{array}{l}\text { Residential care } \\
\text { already equipped } \\
\text { with ST }\end{array}$ & $\begin{array}{l}\text { North } \\
\text { America }\end{array}$ & ND \\
\hline Boll et al. [27] & IV & Qualitative & Acceptance and usability & $\begin{array}{l}\text { Reminder system/ personal } \\
\text { household assistant. }\end{array}$ & NA & Europe & ND \\
\hline $\begin{array}{l}\text { Carabalona et } \\
\text { al. [46] }\end{array}$ & IV & $\begin{array}{l}\text { Descriptive/ } \\
\text { qualitative }\end{array}$ & $\begin{array}{l}\text { To compare usability of } \\
\text { different types of } \mathrm{BCl} \text {. }\end{array}$ & $\begin{array}{l}\mathrm{BCl} \text {-method to enable interaction and } \\
\text { control of devices using EEG signals. }\end{array}$ & $\begin{array}{l}\text { Smart home built } \\
\text { in laboratory } \\
\text { setting }\end{array}$ & Europe & Consecutive \\
\hline Courtney [28] & IV & Qualitative & Acceptance and perceptions & $\begin{array}{l}\text { Bed, kitchen and motion detectors } \\
\text { and fall sensors. }\end{array}$ & $\begin{array}{l}\text { Residential care } \\
\text { facility-no skilled } \\
\text { nursing care }\end{array}$ & $\begin{array}{l}\text { North } \\
\text { America }\end{array}$ & ND \\
\hline $\begin{array}{l}\text { Courtney et al. } \\
\text { [29] }\end{array}$ & IV & Qualitative & Acceptance & $\begin{array}{l}\text { Sensors: Bed, motion, kitchen safety } \\
\text { and falls detection. }\end{array}$ & Retirement Village & $\begin{array}{l}\text { North } \\
\text { America }\end{array}$ & ND \\
\hline Craig et al. [45] & III-2 & Cohort study & $\begin{array}{l}\text { Effectiveness of ST at } \\
\text { assisting ADLs }\end{array}$ & $\begin{array}{l}\text { Hands free environmental control } \\
\text { system e.g., using brain signals to } \\
\text { control their television. }\end{array}$ & Home & $\begin{array}{l}\text { Australia/ } \\
\text { Oceania }\end{array}$ & ND \\
\hline Study & $\begin{array}{l}\text { Level of } \\
\text { evidence }\end{array}$ & Study design & Study aims & Description of ST & Setting of ST & Region & $\begin{array}{l}\text { Sampling } \\
\text { strategy }\end{array}$ \\
\hline Davenport [30] & IV & Qualitative & $\begin{array}{l}\text { Initial reactions of an elderly } \\
\text { person in a smart-house }\end{array}$ & $\begin{array}{l}\text { Smart wave (microwave), floor } \\
\text { tracking system, security system and } \\
\text { voice activated applications. }\end{array}$ & $\begin{array}{l}\text { GatorTech smart } \\
\text { house }\end{array}$ & $\begin{array}{l}\text { North } \\
\text { America }\end{array}$ & ND \\
\hline Demiris et al. [31] & IV & Qualitative & Acceptance and perceptions & $\begin{array}{l}\text { Including bed sensors, gait monitor, } \\
\text { stove sensor, motion sensor and } \\
\text { video sensor }\end{array}$ & Retirement Village & $\begin{array}{l}\text { North } \\
\text { America }\end{array}$ & ND \\
\hline Demiris et al. [32] & IV & Qualitative & Acceptance and perceptions & $\begin{array}{l}\text { Various sensors including motion, } \\
\text { pressure temperature sensors } \\
\text { throughout facility }\end{array}$ & Retirement Village & $\begin{array}{l}\text { North } \\
\text { America }\end{array}$ & ND \\
\hline $\begin{array}{l}\text { Demiris et al. } \\
(2008)[33]\end{array}$ & IV & Qualitative & Perceptions and expectations & $\begin{array}{c}\text { Sensors and cameras-minimal } \\
\text { description }\end{array}$ & Retirement Village & $\begin{array}{l}\text { North } \\
\text { America }\end{array}$ & ND \\
\hline Franco et al. [34] & IV & Qualitative & Feasibility & $\begin{array}{l}\text { Sensors to detect electricity use to } \\
\text { determine activities }\end{array}$ & Home & Europe & ND \\
\hline $\begin{array}{c}\text { Govercin et al. } \\
{[35]}\end{array}$ & IV & Qualitative & $\begin{array}{l}\text { Requirements and feasibility } \\
\text { for sensors }\end{array}$ & $\begin{array}{l}\text { Optical fall sensors and wearable fall } \\
\text { sensor }\end{array}$ & NA & Europe & ND \\
\hline Study & $\begin{array}{l}\text { Level of } \\
\text { evidence }\end{array}$ & Study design & Study aims & Description of ST & Setting of ST & Region & $\begin{array}{l}\text { S a m p I i n g } \\
\text { strategy }\end{array}$ \\
\hline Johnson et al. [36] & IV & Qualitative & Feasibility and acceptance & $\begin{array}{l}\text { Floor tracking system, remote } \\
\text { monitoring system, voice activated } \\
\text { commands, smart wave, smart doors }\end{array}$ & $\begin{array}{l}\text { GatorTech smart } \\
\text { house }\end{array}$ & $\begin{array}{l}\mathrm{N} \text { o } r \quad \mathrm{r} \\
\text { America }\end{array}$ & ND \\
\hline Judge et al. [37] & IV & Qualitative & Perceptions and feasibility & $\begin{array}{l}\text { Speech-driven environmental control } \\
\text { systems }\end{array}$ & Home & Europe & Convenience \\
\hline Lofti et al. [44] & IV & Descriptive & $\begin{array}{l}\text { Ability of sensors to monitor } \\
\text { activity }\end{array}$ & $\begin{array}{l}\text { Standard set of sensors - movement } \\
\text { and door entry point. }\end{array}$ & Home & Europe & ND \\
\hline Martin et al. [38] & IV & Qualitative & Feasibility and perceptions & $\begin{array}{l}\text { Electronic sensor and user interface } \\
\text { eg sensors for door, presence and } \\
\text { kitchen utensils }\end{array}$ & $\begin{array}{l}\mathrm{S} u \mathrm{p} \mathrm{p} \text { o r t e d } \\
\text { accommodation }\end{array}$ & Europe & Convenience \\
\hline Rosenberg [39] & IV & Qualitative & $\begin{array}{l}\text { Readiness of significant others } \\
\text { and dementia sufferers to use } \\
\text { ST }\end{array}$ & $\begin{array}{l}\text { Assistive technologies such as } \\
\text { devices for planning and reminders, } \\
\text { cell phones, GPS, and a remote } \\
\text { control. }\end{array}$ & NA & Europe & ND \\
\hline $\begin{array}{l}\text { Suryadevara and } \\
\text { Mukhopadhyay } \\
{[40]}\end{array}$ & IV & Qualitative & Elderly wellness monitoring & $\begin{array}{l}\text { Sensors dispersed around the home } \\
\text { to detect ADLs. Including on beds, } \\
\text { chairs, attached to panic buttons and } \\
\text { kitchen and living room appliances. }\end{array}$ & $\begin{array}{l}\text { ND - assume } \\
\text { home }\end{array}$ & Asia & ND \\
\hline Study & $\begin{array}{l}\text { Level of } \\
\text { evidence }\end{array}$ & Study design & Study aims & Description of ST & Setting of ST & Region & $\begin{array}{l}\text { S a m p l i n g } \\
\text { strategy }\end{array}$ \\
\hline Tang et al. [41] & IV & Qualitative & $\begin{array}{l}\text { Impact on adherence } \\
\text { medication plan }\end{array}$ & $\begin{array}{l}\text { Multimedia healthcare system that } \\
\text { incorporates an online medication } \\
\text { plan, recognition of medicine } \\
\text { information and advice, coupled with a } \\
\text { reminder system. }\end{array}$ & $\begin{array}{l}\text { Smart-home (set } \\
\text { in a university } \\
\text { laboratory) }\end{array}$ & Asia & ND \\
\hline Tomita et al. [26] & II & $\mathrm{RCT}$ & $\begin{array}{l}\text { Effectiveness of smart-home } \\
\text { technologies }\end{array}$ & $\begin{array}{l}\text { Multiple sensors, remote controls and } \\
\text { security system }\end{array}$ & Home & $\begin{array}{l}\mathrm{N} \text { o } r \quad \mathrm{t} \\
\text { America }\end{array}$ & Consecutive \\
\hline $\begin{array}{l}\text { van Hoof et al. } \\
{[42]}\end{array}$ & IV & Qualitative & Acceptance and feasibility & $\begin{array}{l}\text { Unattended Autonomous Surveillance } \\
\text { System (incorporating sensors and } \\
\text { voice controls) }\end{array}$ & $\begin{array}{l}\text { Home with } \\
\text { i n c r e a s e d } \\
\text { services }\end{array}$ & Europe & ND \\
\hline
\end{tabular}

Note: Intervention study has been highlighted in bold. ST=Smart-home technologies; level of evidence=grades suggested by the NHMRC; ND=not documented; NA=no applicable; $\mathrm{BCl}=$ brain-computer interface; $\mathrm{EEG}=$ Electroencephalography, $\mathrm{ADLs}=$ activities of daily living; RCT=randomised controlled trial; $\mathrm{GPS}=\mathrm{global}$ positioning system.

Table 3: Study characteristics. 
Citation: Morris ME, Adair B, Miller K, Ozanne E, Hampson R, et al. (2013) Smart-Home Technologies to Assist Older People to Live Well at Home. Aging Sci 1: 101. doi: 10.4172/2329-8847.1000101

Page 5 of 9

\begin{tabular}{|c|c|c|c|c|c|c|}
\hline \multirow{2}{*}{ Study } & \multirow{2}{*}{$\mathbf{N}$} & \multicolumn{2}{|c|}{ Age (years) } & \multirow{2}{*}{ Health characteristics } & \multicolumn{2}{|c|}{ Gender } \\
\hline & & Mean (SD) & Range & & Male & Female \\
\hline Beckwith [43] & 29 & ND & ND & 9 residents (dementia), 10 family members, 8 direct-care staff, 2 managers & ND & ND \\
\hline Boll [27] & 74 & $66(5.3)$ & ND & Only characteristic described was hearing impaired (unsure of number) & ND & ND \\
\hline Carabalona [46] & 9 & Median=49 & ND & Neurodegenerative diseases & 3 & 6 \\
\hline Courtney [28] & 14 & ND & $>65$ & ND & ND & ND \\
\hline Courtney et al. [29] & 11 & ND & $>65$ & ND & ND & ND \\
\hline Craig et al. [45] & 10 & $42.9(8.9)$ & ND & Neurological-SCI and profound disability & 8 & 2 \\
\hline Davenport [30] & 1 & 78 & NA & Healthy older adult & 0 & 1 \\
\hline Demiris et al. [31] & 14 & ND & $>65$ & ND & 5 & 9 \\
\hline Demiris et al. [32] & 9 & ND & $>65$ & ND & ND & ND \\
\hline Demiris et al. [33] & 15 & ND & $>65$ & ND & 7 & 8 \\
\hline Franco et al. [34] & 13 & 83 & ND & Health older adults, one with Alzheimer's Disease & 2 & 11 \\
\hline Govercin et al. [35] & 22 & $\begin{array}{l}\text { Group } 1=75 \\
\text { Group } 2=68 \\
\text { Group } 3=66\end{array}$ & $\begin{array}{l}\text { Group 1: } 68-84 \\
\text { Group 2: } 60-76 \\
\text { Group 3: } 50-85\end{array}$ & $\begin{array}{l}\text { Group 1: mod-severe disability with mild-severe risk of falling; Group 2: slight disability with } \\
\text { low falls risk; Group 3: healthy relatives of participants with severe falls risk }\end{array}$ & 6 & 16 \\
\hline
\end{tabular}

\begin{tabular}{|c|c|c|c|c|c|c|}
\hline \multirow[t]{2}{*}{ Study } & \multirow[t]{2}{*}{$\mathbf{N}$} & \multicolumn{2}{|l|}{ Age (years) } & \multirow[t]{2}{*}{ Health characteristics } & \multicolumn{2}{|c|}{ Gender } \\
\hline & & Mean (SD) & Range & & Male & Female \\
\hline Johnson et al. [36] & 18 & 77 & $68-92$ & $\begin{array}{l}\text { Heterogeneous group-group with mobility and visual impairments and one with no } \\
\text { significant impairments }\end{array}$ & 6 & 12 \\
\hline Judge et al. [37] & 12 & $50^{*}$ & $36-68$ & MND, SCI, MS, ACS, quad & ND & ND \\
\hline Lofti et al. [44] & Unclear & ND & ND & Dementia & ND & At least 1 \\
\hline Martin et al. [38] & 7 & NA & NA & Carers of people with dementia & ND & ND \\
\hline Rosenberg et al. [39] & 16 & ND & $45-78$ & Significant others of people with dementia & 5 & 11 \\
\hline $\begin{array}{l}\text { Suryadevara et al. } \\
\text { [40] }\end{array}$ & 4 & ND & ND & ND & ND & ND \\
\hline Tang et al. [41] & 5 & ND & $>60$ & Patients needing to take a particular medication & 4 & 1 \\
\hline Tomita et al. [26] & 78 & $\begin{array}{l}\text { Smart homes }=72(6.0) \\
\text { Control }=75.6(3.4)\end{array}$ & ND & $\begin{array}{l}\text { Elderly people living at home with chronic health conditions but no cognitive } \\
\text { impairments }\end{array}$ & 9 & 69 \\
\hline Van Hoof et al. [42] & 12 & 79.2 (at first interview) & $63-87$ & Heterogeneous group & 2 & 10 \\
\hline
\end{tabular}

Note: Intervention study highlighted in bold. $\mathrm{SD}=$ standard deviation; $\mathrm{ND}=$ not documented; $\mathrm{MND}=$ motor neuron disease, $\mathrm{SCl}=\mathrm{spinal}$ cord injury, $\mathrm{MS}=$ multiple sclerosis, $\mathrm{ACS}=$ Arnold-Chiari syndrome, quad=quadriplegia; ${ }^{*}=$ some ages missing in description therefore calculated mean age may be incorrect.

Table 4: Participant characteristics.

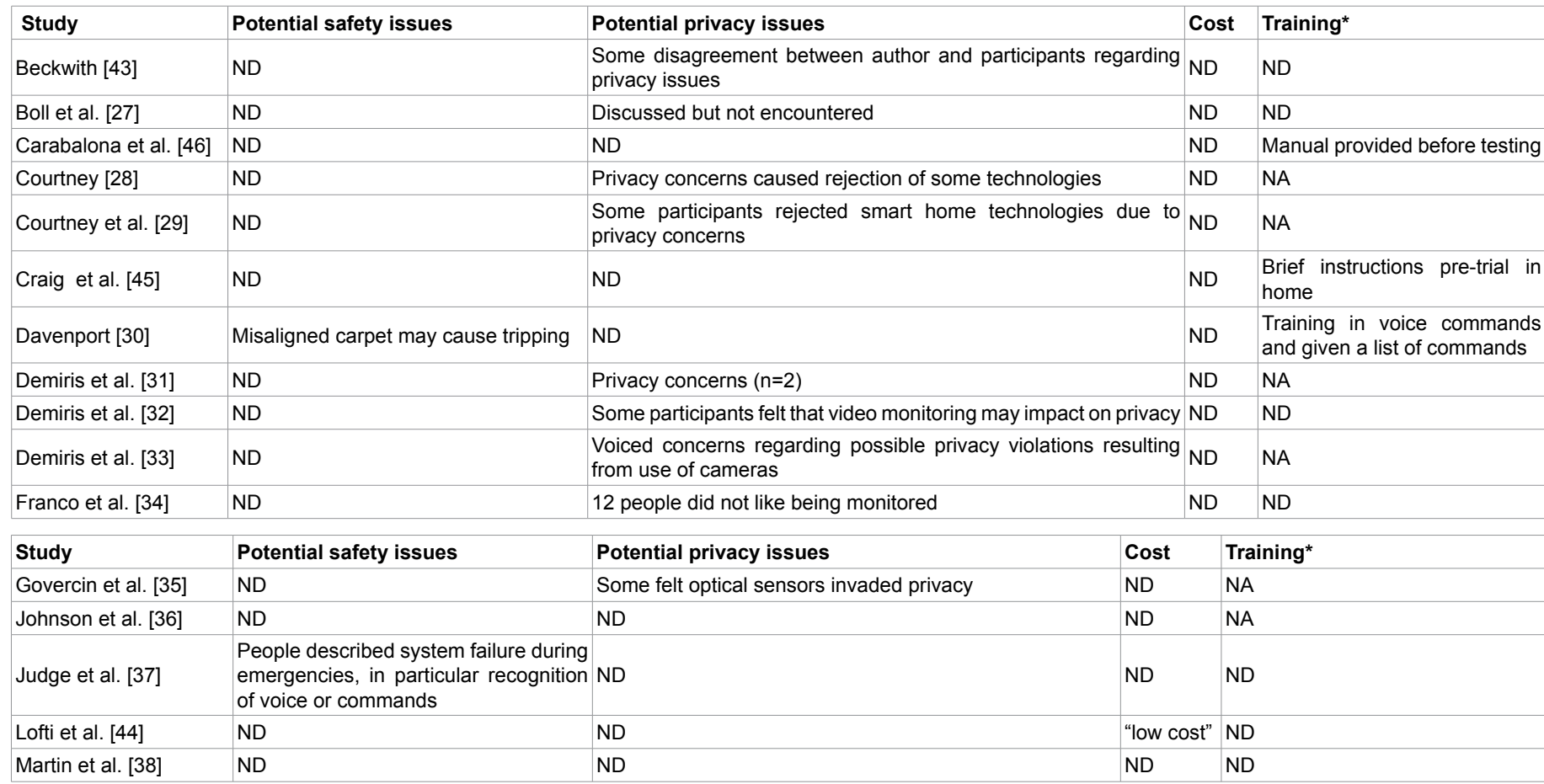




\begin{tabular}{|c|c|c|c|c|}
\hline Rosenberg et al. [39] & ND & $\begin{array}{l}\text { Safety considered more important than privacy while } \\
\text { utilising technology eg GPS }\end{array}$ & ND & NA \\
\hline Suryadevara et al. [40] & ND & ND & "low-cost" & ND \\
\hline Tang et al. [41] & $\begin{array}{l}\text { Possibility raised that the wrong } \\
\text { dosage could be taken }\end{array}$ & ND & ND & ND \\
\hline Tomita et al. [26] & ND & ND & $<\$ 400$ & $\begin{array}{l}\text { Instructions on set-up and the option } \\
\text { of ongoing assistance if necessary }\end{array}$ \\
\hline Van Hoof et al. [42] & $\begin{array}{l}\text { Concerns about not being able to open } \\
\text { electronic doors with a power outage. } \\
\text { Some false alarms noted. }\end{array}$ & $\begin{array}{l}\text { One participant had the ST removed from her home due } \\
\text { to privacy concerns. }\end{array}$ & $<13500 €$ & ND \\
\hline
\end{tabular}

Note: Intervention study highlighted in bold. *=if study documented whether training was required or provided in order to use the smart-technology; ND=not documented; $\mathrm{NA}=$ not applicable because using focus groups to assess perceptions of smart-technology therefore not performed in a particular setting; GPS=global positioning system. Table 5: Feasibility of smart-home technologies.

and thought to be helpful [28,30-33,35-46]. The breakdown of the results for these studies is provided in table 6.

\section{Effectiveness of smart-home technologies}

One randomized controlled trial was identified in this systematic review [26]. This study compared the change in functional status in people who had smart-technologies installed in their homes compared to those with no home modifications. Results from this study suggest that functional status and cognition deteriorate in the general elderly population and that the use of smart technologies may help to maintain these aspects and encourage ageing in place [26]. The results from this study are shown in table 6 .

\section{Quality assessment}

Most of the articles identified in this review were qualitative and few were intervention studies. The investigation by Tomita et al. [26] scored 18 points out of a possible 27 . Several factors were not reported in the article, which impacted on the overall quality assessment score. These included the lack of investigation or reporting of adverse events and the brief description of the source population, blinding, recruitment and sampling methodology.

\section{Discussion}

This systematic review highlights the wide range of smart home technologies currently available to support older adults to live at home. These included passive and active sensors, monitoring systems, environmental control systems and electronic aids to daily living. While a large number of appliances may be available, the review also identified the relatively small number of studies that actually investigated their effectiveness at helping the older adults to live independently at home.

The majority of articles identified in this systematic review were qualitative in design. Some documented whether older adults were able to use smart-home technologies. Other articles addressed the preferences for different technologies and the overall acceptability of devices in the home environment. Qualitative research assists evidence-based, patient-centred care $[47,48]$ and is arguably crucial when attempting to implement changes in the homes of older people. This systematic review found that older adults and health professionals considered smart home technologies to be beneficial. These forms of technology were thought to increase safety and security around the home. Many participants felt that smart-technologies may help to improve their independence. While it was not formally addressed in the identified studies, it is possible that improvements in safety, security and independence may also have a positive effect on quality of life in this population.

The results of this review identify important feasibility issues that should be considered in the development and implementation of the smart home technologies. The primary barrier to the adoption of smarthome technologies by older adults was privacy concerns [28,29,31$35,39,42,43]$. Privacy is therefore a crucial consideration in the design of future smart-home technologies. Most smart-home technologies could be used with little assistance or training. Some safety concerns were identified related to malfunctioning of technology; highlighting the importance of contingency systems for events such as power outages. While the included articles reported varied costs, there were few reports about the cost of smart-technologies. With further commercialization, it is possible that the cost of smart home technologies will reduce, thereby increasing their availability and utilization in home environments.

The results showed that smart-home technologies could accurately detect abnormal movement or behaviours [44] and were appropriate methods to control various electronic devices $[45,46]$. To date, one randomized controlled trial has been performed to assess the effectiveness of smart-home technologies in an elderly population [26]. Longitudinal studies are likely to be required to adequately assess the effectiveness of smart-technologies. Moreover, multiple factors, such as finances, social circumstances, family and level of independence are considered when a person chooses where they will live. For example, a study may assess how long people with smart-technologies can live in their own homes compared with people who do not live in a smarthome. Even if the smart-technologies can physically assist a person, they may move out due to financial stress or to be closer to family members. Future studies may need to consider these aspects in their design, and at least comment on confounders if they cannot be controlled.

Many of the studies identified in this review were performed in North America or Europe. More research may be beneficial to assess the feasibility of smart-technologies specifically in Oceania and Africa. Recently, Western governments have recommended major expansion of housing support services [49]. For example, the Australian agedcare housing industry is now incorporating new technologies to assist older people to live more independently at home and in supported accommodation [50]. Theoretically, people living in rural or remote areas may have different experiences to smart-technologies to people in larger cities. It may also be appropriate to consider assessing the feasibility and effectiveness of smart-home technologies in different communities as well as different countries.

One limitation of this study was the decision to limit the search to articles published in English. The technological advances often found in other regions, such as Asia, may mean that other studies have been conducted on this topic but have been published in other languages and were consequently missed. Given the volume of articles, it was not feasible to include all forms of technology that may assist elderly people to live at home. As a consequence, articles reporting on studies 
Citation: Morris ME, Adair B, Miller K, Ozanne E, Hampson R, et al. (2013) Smart-Home Technologies to Assist Older People to Live Well at Home. Aging Sci 1: 101. doi: 10.4172/2329-8847.1000101

Page 7 of 9

\begin{tabular}{|c|c|c|c|c|c|}
\hline Study & Dosage & $\begin{array}{l}\text { Key dependent } \\
\text { variable }\end{array}$ & $\begin{array}{l}\text { Primary outcome } \\
\text { measure }\end{array}$ & Results & D+B score \\
\hline Tomita et al. [26] & $\begin{array}{l}2 \text { years } \\
\text { full time } \\
\text { in home }\end{array}$ & Functional status & $\begin{array}{l}\text { Primary: FIM. } \\
\text { Secondary: IADL, } \\
\text { mobility subsection } \\
\text { of SIP and CHART }\end{array}$ & $\begin{array}{l}\text { All functional motor measures except for the FIM Motor deteriorated significantly in the } \\
\text { control group but not in the intervention group: SIP Movement }(p<0.001) \text {; IADL }(p<0.05) \text {; } \\
\text { CHART Mobility ( } p=0.002) \text {. FIM cognition scores were significantly higher in intervention } \\
\text { group }(p=0.006) \text {. }\end{array}$ & ; 18 \\
\hline Beckwith [43] & NA & NA & NA & $\begin{array}{l}\text { Ambient intelligence technologies can contribute to increased safety (especially to } \\
\text { reduce falls). }\end{array}$ & NA \\
\hline Boll et al. [27] & NA & NA & NA & $\begin{array}{l}\text { Participants felt that reminders regarding security and safety were important. The evaluation } \\
\text { results show a preference for acoustic presentations, alone or in combination with visual and } \\
\text { tactile output. Many participants felt they would be willing to use the ST in the future. }\end{array}$ & d NA \\
\hline $\begin{array}{l}\text { Carabalona et al. } \\
{[46]}\end{array}$ & NA & NA & NA & $\begin{array}{l}\text { The two forms of } \mathrm{BCI} \text { require the user to have reasonable memory and the good cognitive } \\
\text { function. High degrees of satisfaction were found for both types. Users found the } \mathrm{BCl} \text { that } \\
\text { used icons harder to use than the one which relied on spelling out the task-accuracy for } \\
\text { the character/letter speller }=80 \% \text {, icon speller }=50 \% \text {. }\end{array}$ & NA \\
\hline Courtney et al. [28] & NA & NA & NA & $\begin{array}{l}\text { Participants agreed to some STs but felt they wanted to be able to choose which ones } \\
\text { they needed. Privacy can be a barrier to acceptance of ST unless the participant felt they } \\
\text { needed a particular ST. }\end{array}$ & y $N A$ \\
\hline Study & Dosage & $\begin{array}{l}\text { Key dependent } \\
\text { variable }\end{array}$ & $\begin{array}{l}\text { Primary outcome } \\
\text { measure }\end{array}$ & Results & D+B score \\
\hline Courtney et al. [29] & NA & NA & NA & $\begin{array}{l}\text { Privacy was a barrier for the adoption of smart home technology for some participants. More } \\
\text { often perception of need was the main reason for whether technologies were accepted or not. }\end{array}$ & NA \\
\hline Craig et al. [45] & NA & NA & NA & $\begin{array}{l}\text { Time taken to select an option decreased slightly with } 3 \text { occasions }(p=0.03) \text {, mean number } \\
\text { of errors decreased significantly }(p<0.05) \text {. With practice most participants were able to } \\
\text { reduce their time to select (small reductions). Mean likert score for potential of } S T \text { to control } \\
\text { devices in their own home } 9.45(S D=0.76) \text { [ } 1=\text { not useful, } 10=\text { very useful]. }\end{array}$ & NA \\
\hline Davenport [30] & NA & NA & NA & $\begin{array}{l}\text { The house was able to successfully track the participant's location and frequency with } \\
\text { which ST were utilised. }\end{array}$ & NA \\
\hline Demiris et al. [31] & NA & NA & NA & $\begin{array}{l}\text { Most smart technologies were perceived as useful and most participants would agree to } \\
\text { installation in their own home. Findings indicate an overall positive attitude. }\end{array}$ & NA \\
\hline Demiris et al. [32] & NA & NA & NA & $\begin{array}{l}\text { Residents expressed overall positive perceptions of the sensor technologies and did not } \\
\text { feel that these interfered with their daily activities }\end{array}$ & NA \\
\hline Demiris et al. [33] & NA & NA & NA & $\begin{array}{l}\text { Overall positive response to ST. Emphasised that devices installed in their homes can be of } \\
\text { great benefit when they are reliable, user friendly, can detect a range of emergencies, require } \\
\text { minimal action on the part of the user, have low maintenance costs and are not obtrusive. }\end{array}$ & NA \\
\hline Study & Dosage & $\begin{array}{l}\text { Key dependent } \\
\text { variable }\end{array}$ & $\begin{array}{c}\text { Primary outcome } \\
\text { measure }\end{array}$ & Results & D+B score \\
\hline Franco et al. [34] & NA & NA & NA & $\begin{array}{l}\text { Daily and nocturnal activity could be well differentiated. The probability of having eaten, taken } \\
\text { a bath and going to the toilet could be calculated each day, with eating the most accurate. }\end{array}$ & NA \\
\hline Govercin et al. [35] & NA & NA & NA & $\begin{array}{l}\text { Wearable sensors were preferred over optical sensors because they worked outside the } \\
\text { home. Those with an increased risk of falls were less concerned about privacy. }\end{array}$ & NA \\
\hline Johnson et al. [36] & NA & NA & NA & $\begin{array}{l}\text { Favoured applications depended on individual impairments. Applications that most } \\
\text { people favoured were the smart front door and voice activated commands. Many } \\
\text { participants felt the STs were a good idea but not appropriate for them at the time. }\end{array}$ & NA \\
\hline Judge et al. [37] & NA & NA & NA & Participants felt the ST is occasionally unreliable but can help to improve independence. & NA \\
\hline Lofti et al. [44] & NA & NA & NA & $\begin{array}{l}\text { Was able to detect abnormal behaviors that occurred with medication changes, such as } \\
\text { wandering in the middle of the night. }\end{array}$ & NA \\
\hline Martin et al. [38] & NA & NA & NA & $\begin{array}{l}\text { Overall staff perceived technology in a positive way and felt that ST supported their } \\
\text { work. The service model is innovative and assists care staff to manage risks in a } \\
\text { vulnerable population. }\end{array}$ & NA \\
\hline Study & Dosage & $\begin{array}{l}\text { Key dependent } \\
\text { variable }\end{array}$ & $\begin{array}{c}\text { Primary outcome } \\
\text { measure }\end{array}$ & Results & $D+B$ score \\
\hline $\begin{array}{l}\text { Rosenberg et al. } \\
\text { [39] }\end{array}$ & NA & NA & NA & $\begin{array}{l}\text { Patient's significant others were ready to accept technology if it benefitted the } \\
\text { patients. Technology that enhanced safety, promoted an active lifestyle and } \\
\text { maintained intellectual abilities of the patients were welcomed. Ensuring technologies } \\
\text { were incorporated into existing habits, were flexible and non-stigmatizing were } \\
\text { essential for acceptability. }\end{array}$ & NA \\
\hline $\begin{array}{l}\text { Suryadevara et al. } \\
{[40]}\end{array}$ & NA & NA & NA & $\begin{array}{l}\text { The sensor system registered when a participant was unwell and spent more time in } \\
\text { bed and also when they spent longer amounts of time sitting on one day }\end{array}$ & NA \\
\hline Tang et al. [41] & NA & NA & NA & $\begin{array}{l}\text { Usability: } 3 \text { participants found it easy to use. } \\
\text { Adherence to medication: The context-aware prompting resulted in significantly better } \\
\text { adherence }(90.1 \%) \text { as compared to the non-prompting }(75.8 \%) \text {. }\end{array}$ & NA \\
\hline Van Hoof et al. [42] & NA & NA & NA & $\begin{array}{l}\text { Most participants felt that STs could be used to support ageing-in-place and could be } \\
\text { beneficial where traditional approaches may fail }\end{array}$ & NA \\
\hline
\end{tabular}

Note: Quality assessment scores, dosage and dependent variables are only reported for intervention studies. Intervention study highlighted in bold. $\mathrm{D}+\mathrm{B}=\mathrm{Downs}$ and

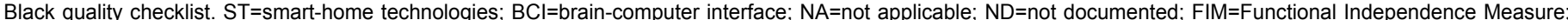
IADL=Duke Older Americans Resources and Services Procedures' IADL; ADL=activities of daily living; SIP=functional mobility subsection of Dysfunction section of Sickness Impact Profile; $\mathrm{CHART}=$ Craig Handicap Assessment and Reporting Technique.

Table 6: Study results. 
Citation: Morris ME, Adair B, Miller K, Ozanne E, Hampson R, et al. (2013) Smart-Home Technologies to Assist Older People to Live Well at Home. Aging Sci 1: 101. doi: 10.4172/2329-8847.1000101

of telemedicine were kept for a separate analysis. There appears to be some cross-over between technologies considered under the guise of telehealth and those under smart-homes. The exclusion criteria and search terminology created a manageable yield for this review but may have resulted in the exclusion of important articles of what some researchers may consider to be smart-home technologies. While appropriate for this review, limiting the articles to studies set in a home environment may have excluded important results collected during laboratory-based investigations.

\section{Conclusion}

A variety of smart-home technologies are available that are readily accepted by older adults and their family members, healthcare professionals and carriers. The feasibility and utilization of smart-technologies can be improved by addressing issues related to safety and privacy. In addition, exploring how feelings of safety and more control over one's life contributes to social and emotional well-being as well as the capacity to continue participating in outside interests and activities. While the outcomes and cost effectiveness of these forms of technology remains to be assessed, they appear to show some potential for helping older adults to live longer, safely and independently in their own homes.

\section{Acknowledgements}

This work was supported by a Grant from the Institute for a BroadbandEnabled Society (IBES). The authors of this study would like to thank Tania Celeste for assistance in developing the search terminology employed during this review.

\section{References}

1. Organisation for Economic Co-operation and Development (2001) World Population Ageing, Paris.

2. Behr R, Sciegaj M, Walters R, Bertoty J, Dungan R (2011) Addressing the housing challenges of an aging population: Initiatives by Blueroof Technologies in McKeesport, Pennsylvania. J Archit Eng 17: 162-169.

3. Ackerman MJ (2009) The smart home. J Med Pract Manage 25: 68-69.

4. Morris ME (2012) Preventing falls in older people. BMJ 345: e4919.

5. Dementia across Australia 2011-2050 (2011) Deloitte Access Economics for Alzheimer's Australia.

6. Caring for Older Australians (2011) Australia Productivity Commission Inquiry Report. Melbourne.

7. Agoulmine N, Deen MJ, Jeong-Soo L, Meyyappan M (2011) U-health smart home: Innovative solutions for the management of the elderly and chronic diseases. IEEE Nanotechnology Magazine 5: 6-11.

8. Morris M, Ozanne E, Miller K, Santamaria N, Pearce A, et al. (2012) Smart technologies for older people: A systematic literature review of smart technologies that promote health and wellbeing of older people living at home. IBES, The University of Melbourne, Australia.

9. McLean A (2011) Ethical frontiers of ICT and older users: cultural, pragmatic and ethical issues. Journal of Ethics and Information Technology 13: 313-326.

10. Menschner P, Prinz A, Koene P, Kobler F, Altmann M, et al. (2011) Reaching into patients' homes-Participatory designed AAL services-The case of a patientcentered nutrition tracking service. Electronic Markets 63-76.

11. Aiello M, Dustdar S (2008) Are our homes ready for services? A domotic infrastructure based on the Web service stack. Pervasive Mob Comput 4: 506525.

12. Floeck M, Litz L (2007)Ageing in place: supporting senior citizens' independence with ambient assistive living technology. MST News 6: 34-35.

13. Skubic M, Alexander G, Popescu M, Rantz M, Keller J (2009) A smart home application to eldercare: current status and lessons learned. Technol Health Care 17: 183-201.

14. Barlow J, Venables T (2004) Will technological innovation create the true lifetime home? Housing Studies 19: 795-810.
15. Martin S, Kelly G, Kernohan WG, McCreight B, Nugent C (2008) Smart home technologies for health and social care support. Cochrane Database Syst Rev 8: CD006412.

16. Pearce AJ, Adair B, Miller K, Ozanne E, Said C, et al. (2012) Robotics to enable older adults to remain living at home. J Aging Res.

17. http://www.merriam-webster.com/netdict.htm.

18. Park H, Chon Y, Lee J, Choi leJ, Yoon KH (2011) Service design attributes affecting diabetic patient preferences of telemedicine in South Korea. Telemed J E Health 17: 442-451.

19. Slavin RE (1995) Best evidence synthesis-an intelligent alternative to metaanalysis. J Clin Epidemiol 48: 9-18.

20. Downs SH, Black N (1998) The feasibility of creating a checklist for the assessment of the methodological quality both of randomised and nonrandomised studies of health care interventions. J Epidemiol Community Health 52: 377-384.

21. Adair B, Said CM, Rodda J, Morris ME (2012) Psychometric properties of functional mobility tools in hereditary spastic paraplegia and other childhood neurological conditions. Dev Med Child Neurol 54: 596-605.

22. Simic M, Hinman RS, Wringley TV, Bennell KL, Hunt MA (2011) Gait modification strategies for altering medial knee joint load: a systematic review. Arthritis Care Res 63: 405-426.

23. Khattak AM, Truc PTH, Hung LX, Vinh LT, Dang VH, et al. (2011) Towards smart homes using low level sensory data. Sensors 11: 11581-11604.

24. Wong AMK (2012) Technology acceptance for an intelligent comprehensive interactive care $(\mathrm{ICIC})$ system for care of the elderly: A survey-questionnaire study. Plos one 7.

25. Croser R, Garrett R, Seegers B, Davies P (2001) Effectiveness of electronic aids to daily living: increased independence and decreased frustration. Aust Occup Ther J 48: 35-44.

26. Tomita MR, Mann WC, Stanton K, Tomita AD, Vidyalakshmi S (2007) Use of currently available smart home technology by frail elders: process and outcomes. Top Geriatr Rehabil 23: 24-34.

27. Boll S, Heusten W, Meyer EM, Meis M (2010) Development of a multimodal reminder system for older persons in their residential home. Inform Health Soc Care. 35: 104-124

28. Courtney KL (2008) Privacy and senior willingness to adopt smart home information technology in residential care facilities. Methods Inf Med 47: 76-81.

29. Courtney KL, Demiris G, Rantz M, Skubic M (2008) Needing smart home technologies: the perspectives of older adults in continuing care retirement communities. Inform Prim Care 16: 195-201.

30. Davenport RD (2007) Pilot live-in trial at the GatorTech smarthouse. Top Geriatr Rehabil 23: 73-84.

31. Demiris G, Hensel BK, Skubic M, Rantz M (2008) Senior residents' perceived need of and preferences for "smart home" sensor technologies. Int J Technol Assess Health Care 24: 120-124.

32. Demiris G, Oliver DP, Dickey G, Skubic M, Rantz M (2008) Findings from participatory evaluation of a smart home application for older adults. Technol Health Care 16: 111-118.

33. Demiris G, Rantz M, Aud M, Marek K, Tyrer H, et al. (2004) Older adults' attitudes towards and perceptions of "smart home" technologies: a pilot study. Med Inform Internet Med 29: 87-94.

34. Franco GC, Gallay F, Berenquer M, Mourrain C, Couturier P (2008) Noninvasive monitoring of the activities of daily living of elderly people at home-a pilot study of the usage of domestic appliances. J Telemed Telecare 14: 231 235

35. Govercin M, Koltzsch Y, Meis M, Wegel S, Geitzelt M, et al. (2010) Defining the user requirements for wearable and optical fall prediction and fall detection devices for home use. Inform Health Soc Care 35: 177-187.

36. Johnson JL, Davenport R, Mann WC (2007) Consumer feedback on smart home applications. Top in Geriatr Rehabil 23: 60-72.

37. Judge S, Robertson Z, Hawley M, Enderby P (2009) Speech-driven environmental control systems - a qualitative analysis of users' perceptions. Disabil Rehabil Assist Technol 4: 151-157. 
Citation: Morris ME, Adair B, Miller K, Ozanne E, Hampson R, et al. (2013) Smart-Home Technologies to Assist Older People to Live Well at Home. Aging Sci 1: 101. doi: 10.4172/2329-8847.1000101

38. Martin S, Nugent C, Wallace J, Kernohan G, McCreight B, et al. (2007) Using context awareness within the 'Smart home' environment to support social care for adults with dementia. Technol Disabil 19: 143-152.

39. Rosenberg L, Kottorp A, Nygard L (2011) Readiness for Technology Use With People With Dementia: The Perspectives of Significant Others. Journal of Applied Gerontology 30: 510-530

40. Suryadevara NK, Mukhopadhyay SC (2012) Wireless sensor network based home monitoring system for wellness determination of elderly. IEEE Sensors Journal 12: 1965-1972.

41. Tang L, Zhou X, Yu Z, Liang Y, Zhang D, et al. (2011) MHS: A multimedia system for improving medication adherence in elderly care. IEEE Systems Journal 5: 506-517.

42. van Hoof J, Kort HS, Rutten PG, Duijnstee MS (2011) Ageing-in-place with the use of ambient intelligence technology: Perspectives of older users. Int J Med Inform 80: 310-331.

43. Beckwith R (2003) Designing for ubiquity: the perception of privacy. IEEE Pervasive Computing 2: 40-46.

44. Lotfi A, Langensiepen C, Mahmoud SM, Akhlaghinia MJ (2010) Smart homes for the elderly dementia sufferers: Identification and prediction of abnormal behaviour. J Ambient Intell Humaniz Comput.

45. Craig A, Moses P, Tran Y, Mclssac P, Kirkup L (2002) The effectiveness of a hands-free environmental control system for the profoundly disabled. Arch Phys Med Rehabil 83: 1455-1458.

46. Carabalona R, Grossi F, Tessadri A, Castiglioni P, Caracciolo A, et al. (2012) Light on! Real world evaluation of a P300-based brain-computer interface (BCl) for environment control in a smart home. Ergonomics 55: 552-563.

47. Giacomini MK, Cook DJ (2000) Users' guides to the medical literature: XXIII. Qualitative research in health care B. What are the results and how do they help me care for my patients? Evidence-Based Medicine Working Group JAMA 284: 478-482.

48. Lee AP (2011) Patient-centered research. Physiotherapy 98: 180.

49. Australian Government (2012) Department of Health and Ageing, Living longer. Living better. Commonwealth of Australia, Canberra, Australia.

50. Australian Government (2011) National Digital Economy Strategy, Department of Broadband, Communications and the Digital Economy, Canberra, Australia. 